\title{
Protecting and SuPPORTING The ORPHAN Fund: RECENT LEgISLATIVE AND AEUB POLICY AMENDMENTS DESIGNED TO ADDRESS UNFUNDED LIABILITIES OF OIL AND Gas FaCILITIES IN Alberta
}

\section{DANIELLE BREZINA AND BRADLEY GILMOUR*}

Recent changes to the Oil and Gas Conservation Act have given regulatory bodies a broader mandate in relation to abandoned wells in Alberta; as set out primarily in Part 11, "Orphan Fund," but elsewhere as well. These legislative changes have important implications for the oil and gas industry due to the expanded scope of the Orphan Fund as regards liability, suspension and abandonment obligations and costs, and the related accountability of directors, officers and agents. This article discusses these changes and how they have been given substance through policy developments and regulatory decisions.
Suite aux récents changements à la Oil and Gas Conservation Act, les organismes de réglementation se sont vu confier un mandat plus large relativement aux puits abandonnés en Alberta en vertu de ce qui est essentiellement énoncé dans la partie 11, intitulée "Orphan Fund (fonds sans agent)", mais aussi ailleurs. Ces changements législatifs ont des implications importantes pour le secteur pétrolier et gazier en raison de la portée élargie de ce "Orphan Fund" en ce qui concerne la responsabilité, les obligations de suspension et d'abandon et les coûts, ainsi que la responsabilité connexe des administrateurs, des dirigeants et des agents. Cet article porte sur ces changements et de quelle manière les développements politiques et les décisions réglementaires leurs ont donné du poids.

\section{TABLE OF CONTENTS}

I. INTRODUCTION ............................... 30

II. SCOPE OF LIABILITY UNDER THE AMENDED OGCA $\ldots \ldots \ldots \ldots \ldots . \ldots 32$

III. LIABLE FOR WHAT? . . . . . . . . . . . . . . . . . . . . . . . 34

A. SUSPENSION AND ABANDONMENT OBLIGATIONS $\ldots \ldots \ldots \ldots \ldots . \ldots \ldots$

B. SUSPENSION, ABANDONMENT AND RECLAMATION COSTS . . . . 36

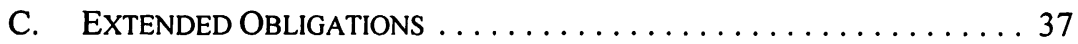

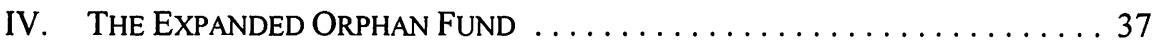

V. ACCOUNTABLE DiRECTORS, OfFICERS AND AGENTS $\ldots \ldots \ldots \ldots \ldots 39$

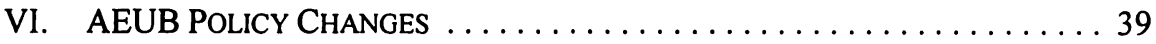

A. EXPANDED ORPHAN PROGRAM IMPLEMENTATION $\ldots \ldots \ldots \ldots \ldots \cdot 39$

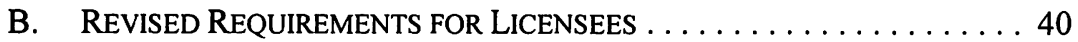

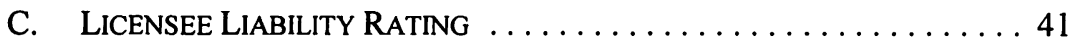

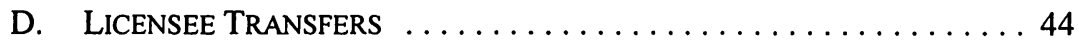

E. MONTHLY ASSESSMENTS . . ................... 45

F. DETAILED REVIEW OF LLR ASSESSMENTS $\ldots \ldots \ldots \ldots \ldots \ldots 45$

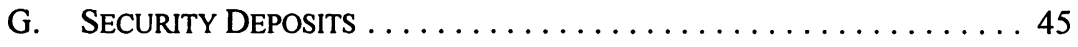

H. TRANSFER OF LICENCES FOR ABANDONED

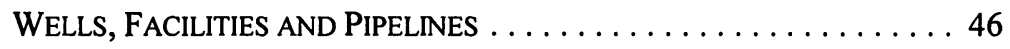

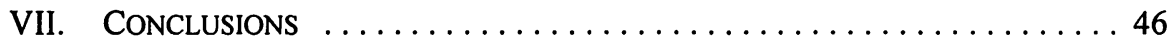

APPENDIX 1 LICENSEE LIABILITY FORMULA $\ldots \ldots \ldots \ldots \ldots \ldots \ldots 47$

Danielle Brezina, Counsel, Alberta Energy and Utilities Board and Bradley Gilmour, Associate, Bennett Jones LLP, Calgary, Alberta. The views expressed in this paper are the views of the authors only and are not intended to represent the views of the Alberta Energy and Utilities Board. 


\section{INTRODUCTION}

The Oil and Gas Conservation Act ${ }^{1}$ was amended, effective 30 June 2000, primarily for the purposes of implementing, protecting and supporting an expanded abandonment fund, now referred to as the Orphan Fund. The pre-amendment abandonment fund covered well abandonment costs in cases where the party responsible for such costs was defunct or financially unviable. The Orphan Fund has an expanded scope and includes suspension, abandonment and related "reclamation"' costs associated with wells, facilities and pipelines. ${ }^{3}$ Various amendments were also made to the Pipeline $A c t^{4}$ for similar purposes. ${ }^{5}$

The amended $O G C A$ requires the licensing of a greater number of upstream facilities ${ }^{6}$ regulated by the Alberta Energy and Utilities Board (AEUB), both on a go-forward basis and retrospectively. The AEUB's Retrospective Facility Licensing Program (RFLP), ${ }^{7}$ which began on 24 October 2000, requires the licensing of many upstream facilities that were not previously licenced by the AEUB. The RFLP not only covers currently operating facilities, but also facilities that are abandoned but not yet reclaimed. Under the RFLP, the AEUB has reviewed its records and issued letters to operators attaching lists of facilities. Operators were deemed to be licensees of the facilities unless disputed by the operator by 21 February 2001 . The result is that the AEUB has identified for its records licensees and working interest participants (WIPs) ${ }^{8}$ for all previously unlicensed facilities. Such records allow the AEUB to identify who may be liable for abandonment and reclamation costs under the $O G C A$. These records may also be used by Alberta Environment for the purpose of issuing environmental protection orders for the clean-up and reclamation of oil and gas wells and facilities under the Environmental Protection and Enhancement Act. ${ }^{9}$

R.S.A. 2000 , c. 0-6 [OGCA].

"Reclamation" is defined as "reclamation within the meaning of the Environmental Protection and Enhancement Act," which is "any or all of the following: (i) the removal of equipment or buildings or other structures or appurtenances; (ii) the decontamination of buildings or other structures or appurtenances or land or water; (iii) the stabilization, contouring, maintenance, conditioning or reconstruction of the surface of land; (iv) any other procedure, operation or requirement specified in the regulations." See Environmental Protection and Enhancement Act, R.S.A. 2000, c. E-12 [EPEA] at s. l(ddd)(i)-(vi).

AEUB, GB 2000-17, Expanded Orphan Program Implementation (28 June 2000).

R.S.A. 2000 , c. P-15 [Pipeline Act].

One distinction of note is that only the licensee of a pipeline is liable for costs of abandonment. The Pipeline Act does not attach liability to working interest participants.

" The word "facility" is defined under the amended act: "except for the purpose of Part 11, means any building, structure, installation, equipment or appurtenance over which the Board has jurisdiction and that is connected to or associated with the recovery, development, production, handling, processing, treatment or disposal of hydrocarbon-based resources or any associated substances or wastes, and includes, without limitation, a battery, a processing plant, a gas plant, and oilfield waste management facility, a central processing facility as defined in the Oil Sands Conservation Regulation [Alta. Reg. 76/88], a compressor, a dehydrator, a separator, a treater, a custom treating plant, a produced waterinjection plant, a produced water disposal plant, a miscible flood injection plant, a satellite or any combination of any of them, but does not include a well, a pipeline as defined in the Pipeline Act, a mine site or processing plant as defined in the Oil Sands Conservation Regulation [Alta. Reg. 76/88] or a mine site or coal processing plant as defined in the Coal Conservation Act."

7 AEUB, ID 2000-10, Retrospective Facility Licensing (24 October 2000); AEUB, Guide 68, Retrospective Facility Licensing (October 2000) rescinded by GB 2002-16.

* A WIP is a person who owns a beneficial or legal undivided interest in a well or facility under agreements that pertain to the ownership of that well or facility.

Supra note 2. 
The amendments to the $O G C A$ also alter the scope of liability for abandonment costs by eliminating any direct liability for directors, officers and others in control of the corporation. However, the $O G C A$ contains powerful new provisions which may hold accountable a director, officer or agent of an entity that owes a debt to the AEUB or the Orphan Fund for suspension, abandonment or reclamation costs, or that is or was otherwise out of compliance with an AEUB Order. Directors, officers and agents may be "declared" by the AEUB as being directors, officers or agents of a non-compliant licensee or WIP. The AEUB may then impose sanctions on licensees or WIPs controlled by "declared" individuals, even when such companies are otherwise in good standing with the AEUB.

A third major element of the amended $O G C A$ is that the AEUB now has authority to determine reclamation costs that have been incurred in respect of a well or facilities and to allocate those costs to WIPs. ${ }^{10}$ Prior to the amendments, Alberta Environment had exclusive jurisdiction over the remediation and reclamation of oil and gas wells and facilities, while the AEUB was responsible for suspension and abandonment. The AEUB had no role in reclamation. The AEUB enforced issues of noncompliance concerning suspension and abandonment, and Alberta Environment had essentially the same role in respect of remediation and reclamation. "The amended $O G C A$ provides the AEUB with jurisdiction to determine and allocate liability for reclamation costs.

A number of new Interim Directives (IDs) and Guides have been issued by the AEUB ${ }^{12}$ in the wake of the amendments to the OGCA. Included within those are the RFLP discussed briefly above, Guide 69, Energy Development Licence Transfer (October 2000), ${ }^{13}$ and ID 2001-8, Revised Licensee Liability Rating (LLR) Program and Energy Development Licence Transfer Requirements (December 2001). ${ }^{14}$ Like the amendments, the purpose of these new IDs and Guides is generally to support and protect the Orphan Fund and reduce the risk of a well or facility becoming orphaned. The purpose of this article is to review and discuss the new provisions of the $O G C A$ and the AEUB's new licence transfer requirements set out in ID 2001-8. ${ }^{15}$

Ibid., s. 30 .

"The AEUB enforces some clean-up and remediation of spills but primarily during the operational life of the facility. The AEUB's authorities in this regard have been broadened with the amendments, and s. 104 now empowers the AEUB to direct a licensee, approval holder or operator to contain and clean up escaped substances of any kind and to do anything else it considers necessary to ensure the safety of the public and the environment in the event of a substance escaping. The AEUB also has the power to carry out such work itself, determine the costs and direct by whom and to what extent they are to be paid. Section 104 is different from the abandonment provisions in that it permits the AEUB to hold an operator of the well, facility or pipeline liable for costs, along with or instead of the licensee/approval holder. Like the abandonment provisions, the AEUB can register any cost order it issues under that section at Queen's Bench and enforce it as a judgment. An "operator" is defined with respect to a well or facility, to mean a person who:

(i) has control of or undertakes the day to day operations and activities at a well or facility, or

(ii) keeps records and submits production reports for a well or facility to the AEUB, whether or not that person is also the licensee or approval holder in respect of the well or facility. Access to AEUB decisions can be obtained from the AEUB's website, online: Alberta Energy and Utilities Board <www.eub.gov.ab.ca/bbs/decisions/default.htm>.

13 Energy Development Licence Transfer (October 2000) AEUB Guide 69.

$14 \quad$ Revised Licensee Liability Rating (LLR) Program and Energy Development Licence Transfer Requirements (4 December 2001) AEUB ID 2001-8. 


\section{SCOPE OF LiABILITY UNDER THE AMENDED OGCA}

Prior to the amendments, the $O G C A^{16}$ had relatively limited provisions ${ }^{17}$ in terms of whom the AEUB could require to abandon a well or pay for well abandonment costs. Generally, liability was limited to the current licensee according to the AEUB's records and any WIPs. These parties were liable for abandonment costs in accordance with their percentage interest in a well, although there was actually a potential conflict in the Act in this regard. Under s. 20.3, the WIPs were liable for abandonment costs in accordance with their proportionate shares, but s. 92 stated that the licensee was liable for abandonment costs where the work was carried out by the AEUB. This issue was addressed and reconciled by the AEUB in Legal Oil \& Gas Ltd., Charles W. Forester, and Tartan Energy Inc. Review of Abandonment Order No. $A D 98-10,{ }^{18}$ wherein the AEUB found a bare licensee (holding 0 percent working interest) and the 100 percent WIP to be jointly and severally liable for abandonment costs where the AEUB had carried out the abandonment.

The old $O G C A^{19}$ also imposed potential liability on persons in "actual control of the corporation" (suggesting potential liability for directors and officers) and certain "deemed" WIPs. In s. 20.1, a "person in actual control of a corporation" was stated to include (but was not expressly limited to) a person referred to in s. 2(2) of the Business Corporations Act. ${ }^{20}$ The AEUB explained its interpretation and application of this personal liability provision in South Alberta Energy Corp., Greg Justice, 693040 Alberta Ltd. and Marc Dame Review of Abandonment Costs Order No. ACO 98-1, ${ }^{21}$ and in Legal Oil..$^{22}$ Another decision of the AEUB regarding this provision is expected in June 2002, relating to Prince Resource Corporation and Richard Yu Review of Abandonment Costs, Order ACO-2001. ${ }^{23}$

If abandonment costs could not be recovered from this limited group of parties, then the costs would usually be recovered through the industry-funded abandonment fund implemented in 1994.

Section 20.1 was repealed with the amendments, so under the amended $O G C A$ there does not appear to be any direct risk of liability to directors, officers or controlling shareholders for the abandonment liabilities of the corporation. Liability for abandonment and reclamation

R.S.A. 1980 , c. O-5, s. $20.2,20.5$.

As compared to the very broad liability net for remediation and reclamation obligations under the $\dot{E} P E A$.

(13 February 2001) AEUB Decision 2001-11, online: AEUB <www.eub.gov.ab.ca/bbs/decisions/ default.htm $>$ [Legal Oil].

R.S.A. 1980 , c. O-5.

S.A. 1981, c. B-15 [Business Corporations Act]. Section 2(2) states that:

For the purposes of this Act, a body corporate is controlled by a person if

(a) securities of the body corporate to which are attached more than $50 \%$ of the votes that may be cast to elect directors of the body corporate are held, other than by way of security only, by or for the benefit of that person, and

(b) the votes attached to those securities are sufficient, if exercised, to elect a majority of the directors of the body corporate.

(17 July 2000) AEUB Decision 2000-51, online: AEUB <www.eub.gov.ab.ca/bbs/decisions/ default.htm $>$ [South Alberta].

Supra note 18.

(June 2002), AEUB Decision 2002-053, online: AEUB <www.eub.gov.ab.ca/bbs/decisions/ energydecisions/2002/2002-053.htm>. 
costs (reclamation costs are discussed below) is limited to the "licensee" (or approvalholder ${ }^{24}$ ) according to the AEUB's records and WIPs.

The word "licensee" is defined under the amended $O G C A$ as "the holder of a licence according to the records of the Board, and includes a trustee or receiver-manager of property of a licensee." ${ }^{25}$ WIPs include those that own a beneficial or legal undivided interest in a well or facility under ownership agreements. WIPs that may be liable are not limited to those that appear on the AEUB's records. Ownership agreements in addition to the AEUB's records determine the liability of WIPs for abandonment and reclamation costs. This is necessary as the AEUB only obtains information as to WIPs at certain points in the life of a well or facility (upon application for an identification code or licence, upon transfer, or upon specific request). The AEUB does not control or regulate the commercial transfer of ownership interests in the way it controls and regulates the transfer of AEUB licences and approvals. The AEUB may obtain updated information as to WIPs upon request, and where the information is contested it may determine who meets the definition of a WIP through examination of agreements. Such analysis occurred and is reflected in South Alberta ${ }^{26}$ and Legal Oil. ${ }^{27}$ In those cases, parties named as liable for abandonment costs disputed their liability by denying that they held a working interest, notwithstanding the existence of agreements purporting to convey such interests.

Section 31 allows the AEUB to deem a former WIP as a continuing WIP where the successor WIP fails to pay its share of suspension, abandonment or reclamation costs, the successor is not the licensee, and the transaction (from former WIP to successor WIP) occurs after the well has ceased to meet the economic limit test prescribed in the regulations, or after the facility has ceased operation or had a throughput less than the rate prescribed in the regulations. Such situations are thought to pose a greater risk to the Orphan Fund, as the well or facility carries greater liability than earning potential. This provision essentially authorizes the AEUB to "look back" in circumstances where there appears to be blatant dumping of liabilities. These deemed WIPs can be held responsible for suspension and abandonment obligations and liable for suspension, abandonment and reclamation costs. Therefore, former WIPs are at risk of being held responsible for liabilities associated with uneconomic wells and facilities even after the interests and associated licenses have been transferred. This continuing liability would only seem to exist when the defaulting WIP is not the licensee of the well or facility. Thus former WIPs are only potentially liable for successor WIPs who are not the licensee. It would appear that implementation of the deemed WIP provisions require regulations setting out economic limit and facility throughput tests. No such regulations were in force as of the writing of this article.

Once deemed, it is not clear whether the party would be liable for its former proportionate share or for the proportionate share of the defaulting successor. It is also not clear whether

"Approval holder" means the holder of an approval granted pursuant to the $O G C A$, any predecessor of the Act, or a regulation under any of them.

25 Supra note 1 at s. 1(1)(cc) [emphasis added].

26. Supra note 21. Leave to appeal was granted by the Court of Appeal, however, the appellant has not pursued the matter. 
liability under s. 31 is limited to the next successor in line or whether liability could extend through to multiple successor WIPs.

In summary, under s. 31 of the $O G C A$, parties who may be held responsible for suspension and abandonment obligations and liable for suspension, abandonment and reclamation costs under the amended legislation include the following:

(a) the holder of an approval issued under the $O G C A$ or predecessor legislation or regulations;

(b) the holder of a licence according to the records of the AEUB;

(c) a trustee or receiver-manager of the property of a licensee;

(d) a WIP; and

(e) a deemed WIP.

The AEUB's usual approach to bankruptcies and receiverships has been to require the trustee/receiver/receiver-manager to carry out abandonment obligations associated with nonproducing or inactive wells to the extent it can using proceeds of the estate, either by carrying out the work or by posting security deposits to secure these liabilities as a condition of transfer of the estate's valuable wells. This approach is consistent with that set out in EPEA in s. 240(3), which limits a receiver, receiver-manager or trustee's liability under an environmental protection order (EPO) to the value of the estate's assets, unless the situation identified in the EPO resulted from or was aggravated by their gross negligence or willful misconduct. The Alberta Court of Appeal confirmed this approach by the Energy Resources Conservation Board (predecessor to the AEUB) in the case of Panamericana de Bienes $y$ Servicios, S.A. v. Northern Badger Oil \& Gas Ltd. ${ }^{28}$ By enforcing abandonment obligations (a public duty) as opposed to abandonment costs (a debt), the Board avoids subordination of these obligations to other claims in the bankruptcy or receivership. See Matrix Resources Ltd. Application to Transfer Well and Pipeline Licences ${ }^{29}$ for the AEUB's views on how the bankruptcy of a licensee affected a transfer application. ${ }^{30}$

\section{LIABLE FOR WHAT?}

\section{A. SuSpension ANd Abandonment Obligations}

Section 27 of the $O G C A$ requires licensees, approval-holders and WIPs to suspend or abandon a well or facility when directed to by the AEUB or as required by the regulations. As discussed below, the amended $O G C A$ grants the AEUB authority to determine and allocate reclamation costs, but it does not provide the AEUB with powers to order reclamation - that authority remains with Alberta Environment under the EPEA. Section 4(b) of the $O G C A$ was amended to state expressly that the purposes of the $O G C A$ included

(1991), 8 C.B.R. (3d) 31, (1991) 86 D.L.R. (4th) 567 (Alta. C.A.).

(24 February 1999), AEUB Decision D99-03, online: AEUB <www.eub.gov.ab.ca/bbs/decisions/ default.htm> [Matrix Resources $]$.

In that case, the trustee was objecting to the transfer and presented the AEUB with a court order stating that no assets of the bankrupt licensee (Legacy Petroleum) were to be transferred without the written approval of the trustee. The AEUB held that the effect of the order was to negate the validity of the original transfer documents executed by Matrix and Legacy, and that it could not approve the transfers in the absence of a new transfer document signed by the trustee, or consent of the trustee. 
the securing and observance of safe and efficient practices in not only abandoning wells and facilities, but also in suspending them. Securing safe and efficient practices in respect of reclamation was not added to the purposes of the $O G C A$. Thus, the AEUB's authority in terms of imposing regulatory obligations in respect of wells and facilities would appear not to extend to reclamation practices generally.

Section 27 provides the AEUB with express authority to order a well or facility suspended or abandoned where the AEUB considers it necessary to protect the public or the environment. Other triggers for abandonment are set out in the Oil and Gas Conservation Regulations, ${ }^{31}$ such as in s. 3.068. Prior to the amendments, s. 20.2 (now s. 27) was limited to the abandonment of wells. The word "suspension" is defined to mean "the temporary cessation of operations at a well or facility in the manner prescribed by the regulations and includes any measures required to ensure that the well or facility is left in a safe and secure condition." 32 "Abandonment" is defined as the "permanent dismantlement of a well or facility in the manner prescribed by the regulations and includes any measures required to ensure that the well or facility is left in a permanently safe and secure condition." ${ }^{33}$

Section 28 allows the AEUB to authorize any other person or itself to suspend or abandon a well where it has not been done so in accordance with the AEUB's direction or the regulations. The AEUB uses this power to suspend or abandon wells and facilities which have orphan status or where licensees are seriously non-compliant. The latter occurs under its enforcement process. It should be noted that the $O G C A$ does not grant the AEUB authority to carry out reclamation of a well or facility, nor to authorize any other person to do so, although on occasion the AEUB has obtained such authority by way of an Order in Council.

Section 29 states that, subsequent to a well being abandoned, licensees, approval-holders and WIPs continue to be responsible for any future requirement to control or abandon further any well or facility or to pay any associated costs. Accordingly, licensees and WIPs are liable, and will continue to be liable, for certain abandoned wells and facilities that they currently own even after they have been abandoned in accordance with the AEUB's requirements. The section does not create a continuing responsibility for reclamation and reclamation costs, which is covered under the EPEA. However, ss. 16 and 17 of the amended $O G C A$ state that the liability of a licensee to, among other things, reclaim a well or facility site continues notwithstanding the cancellation or suspension of a licence under those sections. This should ensure that cancellation or suspension of a licence under those sections does not release a licensee from any liability for reclamation it would otherwise have by virtue of the licence. 


\section{B. SUSPENSION, ABANDONMENT AND REClAMATION COSTS}

Section 30(2) of the amended OGCA provides the AEUB with authority to determine "suspension costs," 34 "abandonment costs," 35 and "reclamation costs." ${ }^{36}$ The AEUB may determine these costs when a person who undertook suspension, abandonment, or reclamation makes an application for such a determination to the AEUB, or on its own motion "in the case of a well or facility suspended or abandoned by the Board or by a person authorized by the Board. ${ }^{\prime 37}$ The amendments create new authority for the AEUB in respect of reclamation costs, authorizing it to determine reclamation costs in cases where the person who conducted reclamation makes a claim. This amendment was intended to provide a onewindow approach to the collection of costs from other WIPs by parties who carry out suspension, abandonment and reclamation work. Absent the existence of an Order in Council granting such authority, the AEUB has no general authority to carry out reclamation on its own motion, nor does it have authority to authorize a person to reclaim a well or facility.

Where the AEUB makes a determination of these costs, the AEUB "shall" allocate the costs to WIPs in accordance with their proportionate share, defined as the percentage share equal to the participant's undivided interest in the well or facility. The amendments do not expressly make WIPs jointly and severally liable for suspension, abandonment and reclamation costs under the $O G C A$; however, in some instances the AEUB has found parties jointly and severally liable when applying the abandonment liability provisions of the old OGCA. (See South Alberta, ${ }^{38}$ where the company and its person in control were held jointly and severally liable for the costs, and Legal Oil, ${ }^{39}$ where the bare licensee and 100 percent WIP were held jointly and severally liable given conflicting statutory provisions.)

The AEUB is required to prescribe a time for payment of costs. The AEUB may impose a 25 percent penalty to a WIP who does not pay within the prescribed time frame. The costs of suspension, abandonment and reclamation as determined by the AEUB constitute a debt owing to the person who incurred such costs. An AEUB Order concerning the determination and allocation of costs may be filed at the Court of Queen's Bench and entered as a judgment.

Section 30 provides, therefore, a statutory mechanism for parties to recover suspension, abandonment and reclamation costs from other WIPs. It is important to note that, based on the broad definition of "reclamation," "reclamation costs" may include not only costs associated with land surface reclamation, but also groundwater and soil remediation costs. This is significant because remediation costs can be large relative to abandonment and land surface reclamation costs, and because the EPEA does not provide any mechanism for a party

Ibid., s. 1(1)(yy). "Suspension costs," subject to section 68(g), means the reasonable costs actually incurred in the suspension of a well or facility.

3s Ibid., s. 1(1)(b). "Abandonment costs," subject to section 68(b), means the reasonable costs actually incurred in the abandonment of a well or facility. of a well or facility, and includes such costs associated with assessment for the purposes of applying for a reclamation certificate under the $E P E A$. 
who has incurred such costs to recover from other "operators" or "persons responsible." Under the $E P E A$, a licensee named in an environmental protection order could be held solely liable for remediation and reclamation obligations and costs with no statutory mechanism to recover from WIPs. Licensees would be limited to pursuing recovery of costs from WIPs under commercial agreements and court proceedings. Section 30 provides an opportunity for those who incur suspension, abandonment and reclamation (apparently including remediation) costs to recover from WIPs in what may prove to be a more efficient and effective manner than through the courts. While the AEUB Order may be entered as a judgment of the Court, the AEUB may also sanction a WIP and the parties who control the WIP who fail to comply with a cost order.

\title{
C. EXTENDED OBLigations
}

\section{Section 32 of the $O G C A$ reads:}

\begin{abstract}
Where a provision of this Act or the regulations imposes a responsibility, obligation or liability on a licensee, approval holder or WIP in respect of the operation, suspension or abandonment of a well or facility or in respect of any matter arising out of the operation, suspension or abandonment of a well or facility, the responsibility, obligation or liability extends also to associated equipment and non-licensed facilities that are located on the site or used in connection with the operation, suspension or abandonment of the well or facility, unless such equipment or facilities are exempted from the application of the provision by the regulations. ${ }^{40}$
\end{abstract}

This section broadens the scope of suspension and abandonment obligations to include equipment and facilities that are not licensed by the AEUB, but are "located on site" or "used in connection with the operation, suspension or abandonment" of a licensed well or facility. This section was intended to ensure that equipment and facilities that do not require AEUB licences (for example, single-well batteries or small compressors) which are used in association with wells or facilities (for example, on lease and/or within the same gathering system) do not fall through the regulatory cracks, and the appropriate parties are liable for their suspension and abandonment.

\section{The EXPANDED ORPHAN FUND}

Provisions concerning the Orphan Fund are found in Part 11 of the OGCA. In the amendments, authority was given to delegate certain functions of the Orphan Fund out from the AEUB. The Orphan Fund Delegated Administration Regulation ${ }^{41}$ effected delegations out to a separate legal entity, the Alberta Oil and Gas Orphan Abandonment and Reclamation Association (the Association), which was established to carry out and pay for the actual abandonment and reclamation work on orphan wells, facilities and sites. The AEUB still retains certain powers with respect to the Orphan Fund, and will continue to have administrative and enforcement functions with respect to levying industry, collecting debts owing to the Orphan Fund and administering programs that support and protect the Orphan Fund (for example, security requirements). The separation of functions concerning the Orphan Fund should not pose practical difficulties for parties making applications to the 
AEUB for matters involving the Orphan Fund (such as reimbursements of costs from defaulting WIPs). Applications should still be made to the AEUB directly, and where necessary, the AEUB will forward items to the Association. The Fund Advisory Committee, a joint government-industry committee that advises and makes recommendations to the AEUB regarding the Orphan Fund, continues to exist and will now advise the Association where appropriate.

The purposes of the Orphan Fund, as set out in s. $70(1),{ }^{42}$ are to pay for:

(a) suspension costs, abandonment costs and "related" reclamation costs in respect of orphan wells, facilities, "facility sites" and "well sites" where the work is carried out by the AEUB, Alberta Environment or a person authorized by the AEUB or Alberta Environment;

(b) costs incurred in pursuing reimbursement of the foregoing costs from a debtor;

(c) a "defaulting WIP's" 43 share of such costs that were incurred by a WIP who has taken all "reasonable steps" necessary to collect that share; and

(d) any costs directly related to the operations of the AEUB in respect of the Orphan Fund. $^{44}$

The Orphan Fund does not cover costs associated with all facilities that are licenced under the $O G C A$. Some notable exceptions from coverage under the fund are: (a) gas processing plants with sulphur recovery and storage; (b) oilfield waste management facilities; (c) designated stradle plants; and (d) oil and gas transmission pipelines and certain associated facilities. ${ }^{45}$ It is unclear from the $O G C A$ who would be responsible for suspension and abandonment costs associated with facilities that are excluded from coverage under the Orphan Fund in cases where the licensee and WIPs are insolvent or otherwise defunct. However, the AEUB has generally taken the same approach as with other bankruptcies and receiverships, enforcing obligations of clean up, suspension and abandonment against the trustee, receiver or receiver-manager to the extent assets of the estate permit. In the case of orphan shares of facilities that are not covered by the Orphan Fund, remediation and reclamation costs could be recovered under the $E P E A$ from past operators and others who are "persons responsible" under the EPEA.

References to "facility sites" and "well sites" first appear in the Orphan Fund provisions of the $O C G A$ and apply only to that Part. "Facility sites" are defined to not include any part of a facility site that has been designated as a contaminated site under the $E P E A .{ }^{46}$ Likewise, "well sites" are defined not to include any part of a well site that has been similarly designated under the EPEA. ${ }^{47}$ The purpose of adding these definitions to Part 11 was to protect the Orphan Fund from bearing the costs of seriously contaminated sites. Sites that

Supra note 1 . The above is an abbreviated and modified version of s. 70(1).

"Defaulting WIP" means a WIP who has been deemed to be a defaulting WIP under s. 70(2)(b) of the OGCA.

Supra note 1 at s. $70(1)$

lbid., s. 68(d).

lbid., s. 68(e).

Supra note 2 at s. $68(\mathrm{~h})$ 
have extraordinary contamination issues may be designated as contaminated sites under the $E P E A$ and are thereby excluded from the Orphan Fund. ${ }^{48}$

\section{ACCOUntable Directors, OfFiCERS AND Agents}

Section $106(1)$ of the $O G C A$ is an entirely new provision which may be used to sanction companies controlled by directors, officers or agents of seriously non-compliant companies. The AEUB has new powers to make a declaration concerning certain directors, officers, agents or "other persons who in the Board's opinion were directly or indirectly in control of a licensee, approval holder or WIP." The declaration powers may be exercised by the AEUB when a licensee, approval-holder or WIP: (a) contravenes or fails to comply with an order of the AEUB; or (b) has an outstanding debt to the AEUB or Orphan Fund concerning suspension, abandonment and reclamation costs. Corporations with directors, officers or agents who are the subject of a declaration by the AEUB may be subject to sanctions by the AEUB even if the corporation itself is in compliance with all AEUB requirements. Such sanctions include the following:

(a) suspension of any of the operations of the licensee or approval holder under the $O G C A$ or the Pipeline Act;

(b) rejection of an application for an identification code, licence or approval under the $O G C A$ or the Pipeline Act;

(c) rejection of an application to transfer a licence or approval under the $O G C A$ or the Pipeline Act;

(d) requirement to post abandonment and reclamation deposits prior to the granting or transfer of licence or approval; or

(e) requirement to post abandonment and reclamation deposits for any well or facility. ${ }^{49}$

It should also be noted that s. 106 applies to a contravention or debt regardless of whether it occurred or arose before or after the amendments to the $O G C A$. This section was added to balance the repeal of provisions that attached personal liability to directors and officers. Under the amended $O G C A$, directors and officers have no direct personal liability for suspension or abandonment costs; however, these new provisions may be used to limit their ability to control licensees and WIPs. These provisions provide an alternative enforcement power for the AEUB which may be more efficient than pursuing debts from directors and officers through administrative and court proceedings.

\section{AEUB Policy Changes}

\section{A. EXPANDED ORPhAN PROgRam IMPLEMENTATION}

General Bulletin 2000-17 $7^{50}$ was released by the AEUB on 28 June 2000, announcing a series of new policies and programs designed to support the expanded Orphan Program. The Orphan Program is to be implemented initially through a series of Interim Directives and Guides, ultimately to be supplemented by amendments to the Oil and Gas Conservation 
Regulations, ${ }^{51}$ the Pipeline Regulation, ${ }^{52}$ and possibly the Oil Sands Conservation Regulations. ${ }^{53}$ These regulations are expected to be phased in as required over the next several months.

The components of the Orphan Program implementation plan include: (a) revised requirements to qualify as a licensee; (b) new facility licensing requirements; (c) retrospective facility licensing program; (d) energy development licence transfer requirements; (e) facility and pipeline suspension and abandonment notification requirements; $(f)$ enhanced corporate liability audits; and $(g)$ an expanded orphan levy. ${ }^{54}$ The implementation and recent amendment of some of these programs are discussed in detail below.

\section{B. REVISED REQUIREMENTS FOR LICENSEES}

On 21 September 2000, the AEUB introduced Interim Directive 2000-7, Licence Eligibility and Qualifications for Potential Licensees and Agents, ${ }^{55}$ along with Guide 67, Identification Code and Agent Registration-Application Guide for Potential Licensees. ${ }^{56}$ Anyone applying for a licence or approval under the OGCA or the Pipeline Act must hold an identification code.$^{57}$ Eligibility requirements for an identification code are dependent in part on the category of the applied-for identification code.$^{58}$ Obtaining an identification code for administrative purposes requires minimal information. Identification codes for licenceholding purposes require the following:

1. If a corporation,,$^{59}$ the applicant must be $e^{60}$

a) registered, with an active status, under the Business Corporation Act; ${ }^{61}$

b) incorporated by or under an act of the Legislature other than the Business Corporations Act and approved by the AEUB as a corporation that may acquire or hold a licence;

c) incorporated under the Bank $A c t ;{ }^{62}$

d) a railway company incorporated under an Act of the Parliament of Canada;

e) registered under the Loan and Trust Corporations $A c t ;{ }^{63}$ or

f) an insurance company licensed under the Insurance Act. ${ }^{64}$

Supra note 31.

Alta. Reg. 122/87.

Alta. Reg. 76/88.

Supra note 50.

Licence Eligibility and Qualifications for Potential Licensees and Agents (21 September 2000), AEUB ID 2000-7.

Replacing ID 93-2 Requirements for the Issuance of a Well Licence or Approval of Well Licence Transfers, IL 95-2 Agent Appointments, and IL 94-9 Licence Criteria for Front Companies.

Supra note 1 at s. 21(1).

Supra note 55.

Note that a limited partnership may not hold an identification code that allows for the acquisition of licences. See ibid.

Supra note 1 at s. 20.

Supra note 20.

S.C. 1991, c. 46, B-1.01.

R.S.A. 2000 , c. L-20.

R.S.A. 2000 , c. I-3. 
2. The applicant must be a resident ${ }^{65}$ of the province of Alberta or must appoint an agent within Alberta in accordance with s. 83 of the $O G C A$ and s. 25 of the Pipeline Act.

3. The applicant must have reasonable and appropriate insurance coverage and submit either a certificate of proof of insurance or a statement of the insurer describing the coverage and the effective date of the insurance.

4. The applicant must submit the corporate profile information specified in Guide 67 and sign the declaration on the AEUB identification code application form.

5. The applicant must pay a $\$ 10,000^{66}$ fee as per s. $17.010(1.1)$ of the Oil and Gas Conservation Regulations unless it is waived by the AEUB upon application. ${ }^{67}$

It should also be noted that no person can apply for or hold a licence or approval in a well or facility unless that person is also a WIP. ${ }^{68}$

\section{LiCENSEE LiABILITY RATING}

With the expanded mandate under the amended legislation, the AEUB needed to develop new mechanisms to maintain the Orphan Fund and to minimize the risk of wells or facilities becoming orphaned. Minimizing the risk of orphaned wells and facilities is achieved in part through the AEUB's new rules for licence transfers and corporate liability ratings as set out in ID 2001-8, Revised Licensee Liability Rating (LLR) Program and Energy Development Licence Transfer Requirements ${ }^{69}$ and Guide 69, Energy Development Licence Transfer. ${ }^{70}$

The mechanisms used in the past to support the abandonment fund included the well screening ratio (WSR) as set out in ID 93-2, Requirements for the Issuance of a Well Licence or Approval of Well Licence Transfer. ${ }^{71}$ The WSR was used prior to approving a well licence transfer as a means to assess the ability of both a transferor and a transferee to cover their abandonment liabilities. The WSR was the ratio of each party's active to inactive wells, assuming that the transaction had been approved and completed. If both parties had a WSR of greater then 1.0 then the application would be approved, assuming other requirements were met. If either party failed the test (WSR of less than or equal to 1.0), then a deposit would be required. In such cases parties could request a detailed review by the AEUB involving either an economic limit or cash-flow index assessment. If a well included in a transfer still failed to meet the requirements after a detailed review, then security deposits

"Resident" means:

a) in the case of a corporation, a corporation that has a corporate presence in Alberta and an established corporate office in Alberta with a functional address, carries on business and performs duties on a daily basis, and has staff who can perform and are authorized to carry out all obligations and duties of a licensee, and

b) in the case of an individual, an individual who has an established residence in Alberta with a functional address and who can perform all obligations and duties of a licensee.

This is a non-refundable fee that is submitted to the Orphan Fund.

Supra note 55.

Supra note 1 at ss. $16,17$.

(4 December 2001), AEUB ID 2001-8 [ID 2001-8].

Supra note 13.

Rescinded by ID 2000-11, Energy Development Licence Transfer Requirements and Monthly Corporate Licensee Liability Rating, which was subsequently superceded and rescinded by ID 2001-08, supra note 69. 
were required prior to approving the transfer. The amount of the security deposit was based on the estimated downhole abandonment costs.

Starting in October 2000, the AEUB released a series of policies, including ID 2000-11, Energy Development Licence Transfer Requirements and Monthly Corporate Licensee Liability Rating, ${ }^{72}$ that replaced the long-term inactive well program with a monthly corporate Licensee Liability Rating (LLR) and introduced a new transfer policy that included the LLR and a Transfer Liability Rating (TLR). The LLR and the TLR were ratios of assets to liabilities and were to be used by the AEUB to estimate the degree of risk that a licensee or transfer posed to the Orphan Fund. If a licensee or transfer failed to meet the LLR or TLR then parties were required either to take actions to reduce their liabilities or to post security deposits with the AEUB. In January 2001, the AEUB released GB 2001-5 ${ }^{73}$ announcing that a task group was formed to review immediately the TLR and LLR requirements set out in ID 2000-1 $11^{74}$ because of concerns raised by industry. The task group examined the direct impact of the TLR and LLR processes on the oil and gas industry and the Orphan Fund and made recommendations for changes to the formulas to attain the appropriate balance between the two factors.

On 4 December 2001, the AEUB released ID 2001-8. ${ }^{75}$ The LLR Program became effective 1 May 2002 and replaces ID 2000-11 ${ }^{76}$ and ID 2000-11 Amendment. ${ }^{77}$

The LLR Program was designed to provide the AEUB with a means to assess the risk of a licensee or a proposed licence transfer in respect of abandonment and reclamation liabilities. The program has two means of assessing risk: (a) it assesses the liability risk of a proposed transfer of licences; and (b) it assesses the liability risk of each licensee on a monthly basis. The interim directive ${ }^{78}$ applies to all upstream oil and gas wells, facilities and pipelines that fall within the scope of the Orphan Program. ${ }^{79}$ As discussed earlier, most types of wells, facilities and pipelines licensed by the AEUB are subject to the Orphan Program.

The LLR program attempts to assess a licensee's ability to fund its abandonment and reclamation liabilities by comparing the licensee's "deemed assets" to "deemed liabilities." While the WSR was a ratio of active wells to inactive wells, the LLR is a ratio of cash flow to average costs of abandonment and reclamation for wells and facilities. The new ratio is a ratio of dollars as opposed to a ratio of well numbers.

Generally, "deemed assets" are considered to be the licensee's "eligible Alberta cash flow," and "deemed liabilities" are considered to be the estimated abandonment and reclamation liabilities for all wells, facilities and pipelines that fall within the scope of the Orphan Program.

(24 October 2000), AEUB ID 2000-11 [ID 2001-11].

Important Information on the Expanded Orphan Program (31 January 2001), AEUB GB 2001-5.

Supra note 72.

Supra note 69.

Supra note 72.

Amendment (12 April 2001), AEUB ID 2000-11.

Supra note 69.

Ibid. at Appendix 2, Orphan Program Inclusions and Exclusions. 
The LLR is calculated as follows:

\section{LLR $=$ Deemed assets/Deemed liabilities ${ }^{80}$}

Deemed assets are calculated differently for producers and non-producers. ${ }^{81}$ For producers, deemed assets are calculated by multiplying a licensee's average daily production during the past four months by the five-year rolling average industry netback and then by three years.

For non-producers, deemed assets are calculated using an individual licensee netback instead of the five-year rolling average industry netback. It is the sum of the cash flow derived from facility throughput of water injection/disposal, oil processing and gas processing reported to the AEUB from facilities for which it is a licensee, and cash flow derived from oil and gas production reported to the AEUB from any wells for which it is a licensee. The deemed assets are calculated by multiplying the average daily non-producer volume over the past four months by the licensee's individual netback and then by three years. The netback is the net profit per unit of volume processed or injected.

Deemed liabilities are determined in the same manner for both producers and nonproducers. As stated in ID 2001-08, ${ }^{82}$ the "deemed liability of a licensee is the sum of the calculated abandonment and reclamation liabilities of all wells and facilities for which it is the licensee, adjusted for status (active, inactive, abandoned, and problem site designation) and present value and salvage factors (PVS)." Deemed liabilities also include designated and potential problem site ${ }^{83}$ liabilities, which could include wells, facilities and pipelines.

The abandonment liability for a well is determined using the well liability calculator contained on the AEUB's website. ${ }^{84}$ The calculator takes into account a number of site and well-specific factors. The reclamation liability of a well is determined from the Regional Reclamation Cost Map contained in Appendix 8 of ID 2001-8 which is based on regional reclamation costs reported by Canadian Association of Petroleum Producers and other industry participants.

The abandonment liability of a facility is calculated by multiplying the number of well equivalents for that facility by $\$ 10,000$. Well equivalents are determined by matching the facility to the Facility Well Equivalents Table contained in Appendix 7 of ID 2001-8. ${ }^{85}$ Reclamation liability for a facility is determined by multiplying the number of well

80) The entire LLR formula is attached as Appendix 1 to the paper.

81 A non-producer licensee is a licensee whose sole or primary activity is the operation of a nonsulphur recovery gas plant, gas storage scheme, custom processing facility, and/or water or gas injection well. See ID 2001-8, supra note 69. Ibid.

83. A "potential problem site" is a site identified by the AEUB as having a potential reclamation liability equal to or greater than four times the amount normally calculated for that type of site in that regional reclamation cost area. A "designated problem site" is a site having a reclamation liability, determined by a reclamation cost estimate acceptable to the AEUB, equal to or greater than four times the amount normally calculated for that type of site in a particular reclamation costs area. See ID 2001-8, ibid. at Appendix 6. 
equivalents for that facility by the dollar value specified in the Regional Reclamation Cost Map contained in Appendix 8 of ID 2001-8. ${ }^{86}$

Potential problem sites may be identified during AEUB inspection of facilities. Such inspections may be conducted by the AEUB on its own initiative or at the request of a landowner or Alberta Environment. A site is a potential problem site if it appears during an inspection that the reclamation liability for the site is greater than four times its calculated reclamation liability for that region. Once identified as a potential problem site, the licensee is required to conduct a Phase II Environmental Site Assessment (Phase II ESA) ${ }^{87}$ within a time frame set by the AEUB. The potential problem site designation will be removed if the Phase II ESA concludes that reclamation costs are less than four times those calculated for that region. During the period that the Phase II ESA is being conducted, the monthly LLR will be calculated as if the site were not a potential problem site unless it is transferred. If the potential problem site is part of a transfer application, its liability will be equal to the sum of its calculated abandonment liability and twenty times the calculated reclamation liability for the particular site in that region. If the site is acquired, the transferee's monthly LLR will be calculated on the basis of the higher calculated reclamation liability.

If the Phase II ESA determines that the reclamation liability of the site is equal to or greater than four times the calculated reclamation liability for that site in that region, then the site will become a designated problem site. The monthly LLR will then be calculated using the reclamation liability estimate derived from the Phase II ESA.

The LLR is calculated on a monthly basis for every licensee of a well, facility or pipeline that is subject to the Orphan Program. The LLR is also calculated for the purposes of reviewing a licence transfer application. If the deemed liabilities for a licensee exceed its deemed assets (that is, its LLR is less than 1.0), then the licensee will be required to post a security deposit with the AEUB that is sufficient to cover the difference between the deemed liabilities and deemed assets. Since deemed assets and deemed liabilities are based on provincial averages, the AEUB allows for a detailed review, based on a limited number of factors, in cases where a licensee's LLR is less than 1.0 (discussed below).

\section{LICENSEE TRANSFERS}

The licence transfer process is more fully described in Guide $69 .^{88}$ Under the new rules, the licence transfer process requires the submission of a licence transfer application instead of an assignment document and statutory declaration. The AEUB will only accept a licence transfer application if both the transferor and transferee have identification codes that permit the holding of licences included within the transfer application. When a licence transfer application is received by the AEUB, the LLR of both the transferor and the transferee are calculated. Assuming that the application is approved and the transfers completed, if the calculated LLR of either party is less than 1.0, security deposits may be required.

A "Phase II Environmental Site Assessment" is an assessment conducted according to CSA Standard Z7690-00 Phase II Environmental Site Assessment. It includes all present-day costs to safely remediate and reclaim the site in a timely fashion and in strict adherence to all Alberta regulatory requirements. 
Transfer applications concerning only the transfer of pipeline licenses do not trigger a LLR review unless the pipeline is a designated "problem site." Responsibility and liability for wells, facilities and pipelines included in a transfer application remain with the licensee (or transferor) until the transfer application is approved by the AEUB.

\section{E. MONTHLY ASSESSMENTS}

All licensees of wells, facilities and pipelines that are subject to the Orphan Program will have their LLRs calculated by the AEUB on a monthly basis. ${ }^{89}$ If a licensee has an LLR of less than 1.0, then it may be required to provide security deposits equal to the difference between its deemed liabilities and deemed assets. Monthly assessments commenced on 1 May 2002, and the monthly LLR of each licensee are made available to the public on the AEUB's website.

\section{F. DETAILED REVIEW OF LLR ASSESSMENTS}

The AEUB recognizes that the assets and liabilities of individual licensees may not be accurately reflected through the "deemed asset" and "deemed liability" calculations, since they are based on industry and regional averages. Therefore, if a licensee has an LLR of less than 1.0, it can make application to the AEUB for a detailed review. ${ }^{90}$ The AEUB will only conduct a detailed review in the following three situations: (1) the licensee's LLR is less than 1.0 on implementation of the program; (2) on the first occasion that the licensee's LLR falls to less than 1.0; and (3) the licensee's LLR is less than 1.0 on the annual implementation of a new industry netback.

\section{G. SECURITY DEPOSITS}

A licensee with an LLR equal to or greater than 1.0 is not required to post any security deposits with the AEUB. A licensee with an LLR of less than 1.0 is required to post security deposits with the AEUB equal to the difference between the licensee's deemed liabilities and deemed assets. ${ }^{91}$

Security deposits are now licensee security deposits and do not attach to any particular well or facility. Starting 1 January 2002, the AEUB established separate interest-bearing bank accounts with the Royal Bank of Canada to hold the cash security deposits of each licensee. Security deposits must be made in the form of cash or irrevocable letters of credit. Security deposits are held to secure the abandonment and reclamation obligations of a licensee and are not tied or allocated to any specific well, facility or pipeline. Any site-specific security deposits held by the AEUB pursuant to prior policies were converted to licensee security deposits. The AEUB will only accept security deposits from a licensee or from a trustee, receiver or receiver-manager acting on behalf of the licensee.

Security deposits can be used by the AEUB if a licensee fails to undertake suspension and abandonment obligations when directed to do so by the AEUB. Alberta Environment may 
also use security deposits in cases where the licensee fails to comply with directions from Alberta Environment concerning the remediation or reclamation of a site.

\section{H. TRANSFER OF LICENCES For ABANDONEd WELLS, FACILITIES ANd PIPELINES}

One of the concerns raised by industry in respect of ID 2000-11 $1^{92}$ was the AEUB's position that it would no longer authorize the transfer of licenses for abandoned wells, facilities and pipelines. The AEUB's goal was to lessen the risk to the Orphan Fund by preventing the transfer of unreclaimed wells, facilities and pipelines and thereby create an incentive or need for licensees to address reclamation liabilities. The policy caused difficulties in cases of bankruptcies or receiverships or where companies were reorganizing or winding-up. In such cases, bankrupt or wound-up companies would continue to hold licenses for abandoned wells, facilities and pipelines; security deposits were required to balance the "deemed liabilities." This policy also interfered with transactions that were structured based on the buyer (transferee) taking abandoned wells along with the producing assets. In some cases the proposed transfers were to more financially viable licensees, in which case the policy seemed somewhat contrary to the interest of protecting the Orphan Fund.

In response to these concerns, the AEUB will now allow the transfer of licences for abandoned wells, facilities and pipelines in certain circumstances. Generally, the AEUB's rules for such transfers are:

1. A licence for an abandoned well or facility that does not have a reclamation certificate and a licence for an abandoned pipeline may be transferred provided that the LLR of the transferor and transferee are above 1.0 (assuming the transaction is completed), or if the appropriate security deposits are paid.

2. A licence for an abandoned well or facility that either has a reclamation certificate or does not require a reclamation certificate may not be transferred. ${ }^{93}$

\section{CONCLUSIONS}

Changes to the legislation and programs implemented to support an expanded Orphan Program have brought a few significant changes to how abandonment and reclamation liabilities will be secured and enforced in Alberta. The most recent policies concerning licence security deposits and transfers appear to have addressed many of the concerns expressed by industry in respect of ID 2000-11. ${ }^{94}$ 


\section{APPENDIX 1 \\ LICENSEE LIABILITY FORMULA \\ (Extracted from ID 2001-8)}

The following Licensee Liability Formula is for use by producer and nonproducer licensees. Producers use the industry average netback and nonproducer licensees use their EUB approved licensee netback to determine deemed assets.

$$
L L R=\frac{\text { Deemed Assets* }}{\text { Deemed Liabilities* }}=\frac{\text { Daily } \mathrm{m}^{3} \mathrm{OE} \times \text { Industry or Licensee Netback } \times 3 \text { years }}{\mathrm{A}+\mathrm{B}+\mathrm{C}+\mathrm{D}+\mathrm{E}+\mathrm{F}+\mathrm{G}+\mathrm{H}}
$$

$\mathrm{A}=$ total calculated active well abandonment and reclamation liability $x$ PVS of .75 liability

$\mathrm{B}=$ total calculated active facility abandonment and reclamation liability $x$ PVS of .50

$\mathrm{C}=$ total calculated inactive well abandonment and reclamation liability $x$ PVS of 1.0

$\mathrm{D}=$ total calculated inactive facility abandonment and reclamation liability $x$ PVS of 1.0

$\mathrm{E}=$ total calculated abandoned but uncertified well regional reclamation liability $x$ PVS of 1.0

$\mathrm{F}=$ total calculated abandoned but uncertified facility regional reclamation liability $\mathrm{x}$ PVS of 1.0

$\mathrm{G}=$ total of designated problem site liability at calculated abandonment cost plus site-specific cost estimate to reclaim $x$ PVS of 1.0

$\mathrm{H}=$ total of potential problem site liability:

- for monthly LLR assessment purposes where site has not been transferred, calculated well or facility abandonment and reclamation liability $\mathrm{x}$ sites PVS factor, or

- for licence transfer purposes and, until the required Phase II Environmental Site Assessment has been completed, for subsequent monthly LLR assessment purposes, calculated well or facility abandonment liability +20 times the reclamation liability otherwise calculated for the site x PVS of 1.0

* Formula terms are defined in ID 2001-8, supra note 69, Appendix 4: Producer Deemed Assets, Appendix 5: Nonproducer Deemed Assets and Appendix 6: Producer and Nonproducer Deemed Liabilities 